\title{
Mandibuloacral Dysplasia with Type A Lipodystrophy
}

National Cancer Institute

\section{Source}

National Cancer Institute. Mandibuloacral Dysplasia with Type A Lipodystrophy. NCI

Thesaurus. Code C123417.

A rare, autosomal recessive inherited disorder caused by mutations in the LMNA gene. It is characterized by growth retardation, craniofacial abnormalities with mandibular hypoplasia, skeletal abnormalities with progressive osteolysis of the distal phalanges and clavicles, and mottled or patchy skin pigmentation. The affected individuals have a marked acral loss of adipose tissue with normal or increased adipose tissue in the neck and trunk. 